\title{
The spoilage and adhesion inhibitory effects of Bacillus subtilis against Shewanella and Pseudomonas in large yellow croaker (Pseudosciaena crocea)
}

\author{
Wen ZHANG ${ }^{1}$ (D), Xucong $\mathrm{LV}^{1}$, Zhibin LIU' ${ }^{1}$ Li NI ${ }^{1 *}$
}

\begin{abstract}
Shewanella and Pseudomonas are considered to be the main spoilage bacteria for chilled fish. This work focused on the spoilage and adhesion ability of two spoilage bacteria (Shewanella spp. S-1 and Pseudomonas spp. P-1), and the adhesion inhibitory effects of Bacillus subtilis against the spoilage bacteria in large yellow croaker (Pseudosciaena crocea). We aimed to develop a feasible solution to prolong the shelf life of large yellow croaker. The spoilage and adhesion characteristics of Shewanella spp. and Pseudomonas spp. strains were compared. It was found that Shewanella spp. induced more significant spoilage of large yellow croaker than Pseudomonas spp. at low temperature in vitro. In addition, Shewanella spp. demonstrated stronger adhesion to the intestinal mucus than Pseudomonas spp. in vitro. The results of a one-week feeding experiment showed that Shewanella was more likely to adhere to large yellow croaker intestines than Pseudomonas. The supplementation of B. subtilis strain BS08 effectively inhibited the proliferation of Shewanella and slowed the spoilage process of large yellow croaker.
\end{abstract}

Keywords: large yellow croaker (Pseudosciaena crocea); spoilage and adhesion; Shewanella; Pseudomonas; Bacillus subtilis.

Practical Application: The results of this study may help to further our knowledge of large yellow croaker spoilage and provide potential probiotic solutions to maintain the freshness of large yellow croaker in low-temperature storage.

\section{Introduction}

Large yellow croaker (Pseudosciaena crocea) is one of the most important economically cultured fish species in southeast China. In fact, it is the most cultivated species in Chinese marine net-cage farming (Liu \& Mitcheson, 2008). In order to maintain freshness, large yellow croaker is often stored at low temperature on ice. However, due to the high levels of moisture and nutrient content, air-exposed iced large yellow croaker can easily spoil within a few days.

During storage, the microflora changes, due to different abilities of microorganisms to tolerate the preservation conditions. Some psychrotolerant Gram-negative bacteria (such as Pseudomonas and Shewanella) grow on chilled fish and have been reported as specific spoilage organisms (SSOs) (Gram \& Dalgaard, 2002). Shewanella and Pseudomonas are also considered potential spoilage bacteria in large yellow croaker (Ge et al., 2017). Shewanella is the dominant organism in large yellow croaker at low temperature (Quanyou et al., 2018). To date, studies have focused on quorum sensing (QS) signaling molecules in regulated biofilm formation and spoilage gene expression to clarify the causes of Shewanella-lead spoilage (Zhu et al., 2016; Fu et al., 2018a). Bio-preservatives such as nisin, green tea polyphenols, and bacteriocin, produced by Bacillus coagulans, have been implemented to preserve large yellow croaker through inhibition of quorum sensing and biofilm of Shewanella (Zhu et al., 2015; He et al., 2017; Fu et al., 2018b).

Bacterial adhesion to fish tissue surfaces is an important step in the initial stage of bacterial colonization (Vendrell et al.,
2009). The characteristic s of pathogenic Vibrio alginolyticus adhesion to mucus show that the portal of entry for pathogenic $V$. alginolyticus into large yellow croaker is via the intestinal tract, rather than gill or skin, according to the kinetics of the bacterial adhesion to different mucus types (Chen et al., 2008). The use of probiotics may provide protection through competition for host extracellular matrix-binding sites, thereby blocking the adhesion and spread of pathogens (Reid et al., 2001), such as Bacillus (Etyemez \& Balcazar, 2016; Kavitha et al., 2018) and lactic acid bacteria (Arellano-Ayala et al., 2020; Kos et al., 2003; Nwanna et al., 2014).

However, there have been few studies on the adhesion of spoilage bacteria (including Pseudomonas and Shewanella) to fish. Our previous research showed that Shewanella spp. had stronger surface hydrophobicity and auto-aggregation ability than Pseudomonas spp. which enhanced the adhesion ability to fish mucus and form biofilm (Zhang et al., 2019a). The adhesion ability of Shewanella spp.to gill and intestine were higher than which to skin, which was enhanced with the concentration of $\mathrm{NaCl}$ increased (Zhang et al., 2019b). In this work, we hypothesized that the adhesion and colonization ability of spoilage bacteria plays an important role in the spoilage potential of bacteria. Therefore, the adhesion and spoilage ability of spoilage bacteria (Shewanella and Pseudomonas) to large yellow croaker were investigated and one Bacillus subtilis strain, BS08, was employed to inhibit the adhesion of bacteria and to retain freshness of large yellow croaker during low-temperature storage. 


\section{Materials and methods}

\subsection{Bacterial strains}

Shewanella spp. (S-1) and Pseudomonas spp. (P-1) isolated from iced large yellow croaker and Bacillus subtilis BS08 isolated from bee gut (Zhang et al., 2017) were kept in our laboratory.

\subsection{Spoilage potential evaluation}

Large yellow croakers (approx. $500 \mathrm{~g}$ ) were transported to the laboratory on ice from the aquatic products market in Fuzhou, China, within $6 \mathrm{~h}$ of fishing. Subsequently, they were scaled; the gills and guts were removed. The fish were cleaned and filleted (weigh $2.0 \pm 0.1 \mathrm{~g}$ each). Then, the fillets were washed thoroughly with sterile water, placed in a sterile petri dish, and irradiated with ultraviolet light for $20 \mathrm{~min}$. Sterile fish fillets were soaked in a bacterial suspension of Shewanella spp. or Pseudomonas spp. (approx. $10^{8} \mathrm{CFU} \mathrm{mL} \mathrm{m}^{-1}$ ) for $20 \mathrm{~s}$, drained, and placed in a $50 \mathrm{~mL}$ sterile centrifugal tube. The tube was stored at $4{ }^{\circ} \mathrm{C}$. Sterile fish fillets without inoculated bacteria were used as a blank control.

A fish sample $(2 \mathrm{~g})$ was homogenized with $18 \mathrm{~mL}$ of sterile saline solution for $2 \mathrm{~min}$. Then, 10 -fold serial dilutions were made and inoculated on beef extract peptone medium. Total viable counts (TVC) were determined by counting the number of colony-forming units after incubation at $28^{\circ} \mathrm{C}$ for $24 \mathrm{~h}$.

The fish fillets were homogenized. Appropriate quantities of homogenized fish were used for the determination of the following chemical parameters. Total volatile basic nitrogen (TVB-N) was determined according to a previously published method (Malle \& Poumeyrol, 1989). Trimethylamine (TMA) was determined according to the method of Association of Official Analytical Chemists (1990), with slight modifications. Samples (5 g) were homogenized with $20 \mathrm{~mL}$ sterile distilled water and mixed with $10 \mathrm{~mL}$ of $20 \%$ trichloroacetic acid. After centrifugation at $10,000 \mathrm{~g}$ for $10 \mathrm{~min}, 5 \mathrm{~mL}$ supernatant were mixed with $1 \mathrm{~mL}$ of formaldehyde (10\%), $10 \mathrm{~mL}$ of anhydrous toluene and $3 \mathrm{~mL}$ of $\mathrm{K}_{2} \mathrm{CO}_{3}$ in a tube. The tube was covered immediately and shaken vigorously about 60 times. After standing for $20 \mathrm{~min}$, the $5 \mathrm{~mL}$ toluene layer was transferred to another tube containing $5 \mathrm{~mL}$ picric acid solution $(0.02 \%)$. The absorbance of the mixed solution was measured at $410 \mathrm{~nm}$. The TMA value was calculated by standard curve of TMA (purity $>98 \%$ ). The results of TVB-N and TMA are expressed as mean mg-N $100 \mathrm{~g}^{-1} \pm$ standard deviation of three replicates from different batches.

The K value was estimated according to a previously published method (Yu et al., 2018). Nucleotide standards, including adenosine triphosphate (ATP $\geq 98 \%$ ) nosine diphosphate (ADP $\geq 98 \%$ ), adenosine monophosphate (AMP $\geq 98 \%$ ), inosine monophosphate (IMP $\geq 98 \%$ ), hypoxanthine riboside ( $\mathrm{HxR} \geq 98 \%$ ), and hypoxanthine $(\mathrm{Hx} \geq 98 \%$ ), were purchased from Lanji Co. (Shanghai, China). Samples ( $2 \mathrm{~g}$ ) were homogenized with $7.5 \mathrm{~mL}$ for $3 \mathrm{~min}$ and centrifuged at $10,000 \mathrm{~g}$ for $5 \mathrm{~min}$ at $4{ }^{\circ} \mathrm{C}$. The extraction process was repeated once, and the combined supernatants were neutralized immediately to $\mathrm{pH}$ 6.0-6.4 with $1 \mathrm{~mol} \mathrm{~L}^{-1} \mathrm{NaOH}$ solutions. The precipitate in neutralized solution was removed by centrifugation $\left(3,000 \mathrm{~g}, 5 \mathrm{~min}\right.$ and $\left.4{ }^{\circ} \mathrm{C}\right)$, and the supernatant was diluted to $50 \mathrm{~mL}$ with cold distilled water. The final solution was filtered through a nominal $0.22 \mu \mathrm{m}$ membrane filter, and ATP-related compounds were determined using an L-2000 HPLC (HITACHI, Japan) equipped with a HITACHI L-2455 detector and an Agilent Zorbax SB-C18 column $(4.6 \times 250 \mathrm{~mm}, 5 \mu \mathrm{m})$. The mobile phases were $0.02 \mathrm{M}$ phosphate buffer $\left(\mathrm{KH}_{2} \mathrm{PO}_{4}\right.$ and $\left.\mathrm{K}_{2} \mathrm{HPO}_{4}, \mathrm{pH} 6.0\right)$ and methanol (98:2, v/v), with a flow rate of $1 \mathrm{~mL} \mathrm{~min}^{-1}$. The detection wavelength and column temperature were $254 \mathrm{~nm}$ and $30^{\circ} \mathrm{C}$, respectively. The $\mathrm{K}$ value was calculated using the following Equation 1:

$$
K \text { value }(\%)=\frac{M_{H x R}+M_{H x}}{M_{A T P}+M_{A D P}+M_{A M P}+M_{I M P}+M_{H x R}+M_{H x}} \times 100
$$

\subsection{Bacterial adhesion ability}

Mucus was prepared using the method published by Chen et al. (2008), with a slight modification. The intestinal mucus was harvested by scraping off the inner surface of the intestines with a spatula to remove the mucous gel layer covering the intestine. Finally, the mucus was homogenized in sterile $0.01 \mathrm{~mol} \mathrm{~L}{ }^{1} \mathrm{PBS}$ centrifuged at $4{ }^{\circ} \mathrm{C}$ and centrifuged twice at $10,000 \mathrm{~g}$ for $30 \mathrm{~min}$ to remove particulate matter. The supernatant were filtered through $0.22 \mu \mathrm{m}$ filters. The mucus samples were adjusted to $0.5 \mathrm{mg} \mathrm{mL}^{-1}$ with sterile $0.01 \mathrm{~mol} \mathrm{~L}^{-1} \mathrm{PBS}$ and stored at $-20{ }^{\circ} \mathrm{C}$ until use. The protein concentration was determined by the Lowry method (Hartree, 1972).

FITC staining was performed according to a previously published method (Vinderola et al., 2004). Fresh cultures of each strain were cultured overnight at $28^{\circ} \mathrm{C}$. Then, bacteria were harvested by centrifugation at $10,000 \mathrm{~g}$ for $10 \mathrm{~min}$ at $4^{\circ} \mathrm{C}$ and washed twice with $0.01 \mathrm{~mol} \mathrm{~L}^{-1} \mathrm{PBS}$ ( $\mathrm{pH}$ 7.4). Cells were labelled with fluorescein isothiocyanate (FITC; Sigma, St Louis, MO, USA, $0.2 \mathrm{mg} \mathrm{mL}^{-1}$ ) in PBS and incubated for $1.5 \mathrm{~h}$ at $30^{\circ} \mathrm{C}$ in the dark. Labeled bacteria were washed a few times with $\mathrm{PBS}$ solution to remove unincorporated FITC. The final pellet was resuspended in PBS to a concentration of $1 \times 10^{8} \mathrm{CFU} \mathrm{mL}-1$ and stored at $-20^{\circ} \mathrm{C}$ in the dark.

To black 96-well plates, $150 \mu \mathrm{L}$ of mucus was added and stored overnight at $4{ }^{\circ} \mathrm{C}$. The residual mucus was washed twice with $200 \mu \mathrm{L}$ of sterile $0.01 \mathrm{~mol} \mathrm{~L}^{-1} \mathrm{PBS}$. To the wells, $150 \mu \mathrm{L}$ of FITClabeled bacterial suspension was added and incubated at $4^{\circ} \mathrm{C}$ for $90 \mathrm{~min}$. The non-adhered bacteria were flushed twice with sterile physiological saline. Adhered bacteria were released and lysed with $150 \mu \mathrm{L}$ of a $1 \%$ SDS $\left(0.1 \mathrm{~mol} \mathrm{~L}^{-1} \mathrm{NaOH}\right)$ solution at $60^{\circ} \mathrm{C}$ for $1 \mathrm{~h}$. Fluorescence was measured in a multiscan fluorometer (SpectraMax i3+MiniMax, Molecular Devices, USA) at $\lambda$ ex $495 \mathrm{~nm}$ and $\lambda$ em $525 \mathrm{~nm}$. Negative controls of labeled bacteria were used to calculate the percentage of adhesion. This percentage was expressed as the percentage of fluorescence recovered after attachment to mucus, relative to the initial fluorescence of the bacterial suspension added to the wells (Equation 2).

$$
\text { Adhesion rate } \%=\frac{F_{2}}{F I_{1}} \times 100
$$

where $\mathrm{FI}_{2}$ and $\mathrm{FI}_{1}$ are the fluorescence intensities of the experimental group and the FITC-labeled pure bacterial suspension, respectively. 


\subsection{Adhesion inhibition}

\section{Competition inhibition}

FITC-labeled spoilage bacteria were mixed in equal volume with Bacillus subtilis BS08. To the 96-well plates coated with mucus, $150 \mu \mathrm{L}$ of the bacterial suspension was added and incubated at $28{ }^{\circ} \mathrm{C}$ for $2 \mathrm{~h}$.

\section{Displacement inhibition}

To the 96-well plates coated with mucus, $150 \mu \mathrm{L}$ of FITC-labeled bacterial suspension was added and incubated at $28^{\circ} \mathrm{C}$ for $2 \mathrm{~h}$. The non-adhered bacterial cells were discarded by washing twice with $200 \mu \mathrm{L}$ of sterile $0.01 \mathrm{~mol} \mathrm{~L}^{-1} \mathrm{PBS}$. Next, $150 \mu \mathrm{L}$ of Bacillus subtilis BS08 suspension was added and incubated at $28^{\circ} \mathrm{C}$ for $2 \mathrm{~h}$.

\section{Exclusion inhibition}

To the 96-well plates coated with mucus, $150 \mu \mathrm{L}$ of Bacillus subtilis BS08 suspension was added and incubated at $28{ }^{\circ} \mathrm{C}$ for $2 \mathrm{~h}$. The non-adhered cells were discarded by washing twice with $200 \mu \mathrm{L}$ of sterile $0.01 \mathrm{~mol} \mathrm{~L}^{-1}$ PBS. Next, $150 \mu \mathrm{L}$ of FITC-labeled bacterial suspension was added and incubated at $28^{\circ} \mathrm{C}$ for $2 \mathrm{~h}$.

After incubation for $2 \mathrm{~h}$, the cells were washed twice with $200 \mu \mathrm{L}$ of sterile $0.01 \mathrm{~mol} \mathrm{~L}^{-1} \mathrm{PBS}$. The adhered cells were released and lysed with $150 \mu \mathrm{L}$ of a $1 \% \operatorname{SDS}\left(0.1 \mathrm{~mol} \mathrm{~L}^{-1} \mathrm{NaOH}\right)$ solution at $60{ }^{\circ} \mathrm{C}$ for $1 \mathrm{~h}$. Fluorescence was measured in a multiscan fluorometer (Equation 3).

Inhibition rate $(\%)=1-A_{2} / A_{1} \times 100 \%$

where $A_{1}$ is the fluorescence intensity of the FITC-labeled spoilage bacterial adhered on mucus, and $\mathrm{A}_{2}$ is the fluorescence intensity of the FITC-labeled spoilage bacterial adhered on mucus inhibited by Bacillus subtilis.

\subsection{Feeding experiment}

Basal fish feed was purchased from Fuzhou Haima Feed Co., Ltd. Its main components included fishmeal, flour, soybean meal, fish oil, vitamins, and minerals. Bacillus subtilis strain BS08 was grown in $\mathrm{MNB}$ at $37^{\circ} \mathrm{C}$ in a rotary shaker for $24 \mathrm{~h}$. Bacterial cells were harvested by centrifugation (10,000 $\mathrm{g}$ for $10 \mathrm{~min}$ ) and washed and re-suspended in normal saline solution (NSS). Subsequently, gum arabic was added into the bacterial suspension with a final concentration of $15 \%(\mathrm{w} / \mathrm{v})$. Then, it was spray dried to obtain a bacterial powder with approx. $5 \times 10^{10} \mathrm{CFU}$ $\mathrm{g}^{-1}$. Afterward, $10 \mathrm{~g}$ of the bacterial powder was resuspended in NSS and sprayed on the surface of the basal fish feed (1 kg), forming a probiotic supplemented fish feed (SF) with Bacillus subtilis BS08.

A total of 80 juvenile large yellow croakers, with an average body weight of $20 \mathrm{~g}$, were purchased and kept in a fish farm (Ningde Fufa Aquatic Co., Ltd.). The fish were randomly divided into 2 groups $(n=40)$, including one control group and one treatment group. The fish in the same group were kept in two separated plastic tanks (20 fish per tank, capacity, $100 \mathrm{~L}$ ). The fish in the control group (Con) were fed with basal feed, while the treatment group (SFG) was fed with supplemented fish feed (SF). Feed was supplied twice a day (09:00 and 17:00 h). The cultivation water was marine water with a temperature of $22{ }^{\circ} \mathrm{C}$ to $24^{\circ} \mathrm{C}$. During the experiment, approximately $30 \%$ of cultivation water was changed daily, along with the purge of the unconsumed feed and fish feces. After one week of adaptation with basal feed, the feeding experiment lasted one week.

After $24 \mathrm{~h}$ of fasting at the end of experiment, all fish were caught and stored at $4{ }^{\circ} \mathrm{C}$ immediately. At storage for $1 \mathrm{~d}$ and $3 \mathrm{~d}$, fish were washed with sterile water to reduce contamination by commensal bacteria. Digestive tracts were aseptically removed and homogenized in a sterile homogenization bag. The bags were stored at $-20^{\circ} \mathrm{C}$ for DNA extraction. The fish were scaled; the gills and guts were removed. The fish were cleaned, filleted (weigh $2.0 \pm 0.1 \mathrm{~g}$ each), and stored at $-20^{\circ} \mathrm{C}$ for the TVB-N test.

\subsection{DNA extraction, qPCR reaction, and high-throughput sequencing analysis}

Total DNA was extracted from the intestines using a fecal genomic DNA Extraction Kit and bacterial genomic DNA extraction kit (Tiangen, China), respectively. The qPCR reaction consisted of $2.0 \mu \mathrm{L}$ of 10 -fold diluted DNA, $10 \mu \mathrm{L}$ of SYBR Green, and $0.2 \mu \mathrm{L}$ of each primer $(10 \mu \mathrm{M})$ in a total volume of $20 \mu \mathrm{L}$. The PCR program comprised 45 cycles at $94{ }^{\circ} \mathrm{C}(35 \mathrm{~s}), 60{ }^{\circ} \mathrm{C}$ (30 s) and $72{ }^{\circ} \mathrm{C}(30 \mathrm{~s})$, followed by melt curve generation. Melt curves were analyzed to check the specificity of amplification. Gene-specific primers were designed as:

- Pseudomonas, Pse-F, GCAACGCGAAGAACCTTACC, Pse-R, CATCTCACGACACGAGCTGA;

- Shewanella, She-F, CTTGGGGCGGCTACACAT, She-R, GTGTCTCAGTCCCAGTGTGG;

- Bacillus subtilis, Bac-F, AAAGTCTGACGGAGCAACGC, Bac-R, ACCGCCCTATTCGAACGGTA.

Bacterial primers 341-F (50-CCT AYG GGR BGC ASC AG-30) and 806-R (50-GGA CTA CNN GGG TAT CTA AT-30) were used to amplify the V3-V4 region of bacterial 16SrRNA genes. The sequencing library of bacterial 16S rRNA genes was generated for high-throughput sequencing, employing the TruSeqfi DNA PCR-Free Sample Preparation Kit (Illumina, San Diego, CA, USA). Next, the library was sequenced on an Illumina HiSeq2500 platform by Novogene Bioinformatics Technology Co., Ltd. (Beijing, China).

\subsection{Statistical analysis}

The results are expressed as the mean of three to five independent replicates. Data were analyzed using ANOVA, and the means were compared with Tukey's test (5\% probability), using SPSS 24.0 software. The graphs were prepared with GraphPad Prism 8.0 software. 


\section{Results}

\subsection{Analysis of spoilage ability of Shewanella spp. and Pseudomonas spp.}

Microbiological and biochemical changes are associated with the deterioration of fish quality. The total number of viable bacteria (TVC), total volatile basic nitrogen (TVB-N), trimethylamine (TMA), and $\mathrm{K}$ value are commonly used as indicators of fish spoilage (Chytiri et al., 2004).

Changes in TVC of large yellow croaker fillets inoculated with spoilage bacteria during storage in $4^{\circ} \mathrm{C}$ are shown in Figure 1A. The TVC was $4.10 \log \mathrm{CFU} \mathrm{g}^{-1}$ on day 1 in the control group and increased to $6.64 \log \mathrm{CFU} \mathrm{g}^{-1}$ three days later. The spoilage limit of $7.00 \log$ CFU g ${ }^{-1}$ (Ojagh et al., 2010) was reached after four days of storage. TVC increased rapidly and reached the spoilage limit after three days of storage for the groups inoculated with spoilage bacteria, particularly with Shewanella spp. $(P<0.05)$.

TVB-N values in the control group increased slightly during storage at $4{ }^{\circ} \mathrm{C}$ (Figure 1B). TVB-N on day 1 and day 5 was $16.06 \mathrm{mg}-\mathrm{N} 100 \mathrm{~g}^{-1}$ and $21.54 \mathrm{mg}-\mathrm{N} 100 \mathrm{~g}^{-1}$, respectively. The TVB-N of fillets inoculated with spoilage bacteria increased rapidly during storage, especially for the fillets inoculated with Shewanella spp.. TVB-N values approached the upper acceptable level of 25 mg-N $100 \mathrm{~g} \mathrm{~g}^{-1}$ (Gimenez et al., 2002) after one day of storage in the Shewanella spp. inoculated group and after two days of storage in the Pseudomonas spp. group. The TVB-N values of fillets inoculated with Shewanella spp. were significantly higher than those of fillets inoculated with Pseudomonas spp. after five days of storage, and the TVB-N values reached about $70 \mathrm{mg}-\mathrm{N}$ $100 \mathrm{~g}^{-1}$ and $40 \mathrm{mg}-\mathrm{N} 100 \mathrm{~g}^{-1}$, respectively.
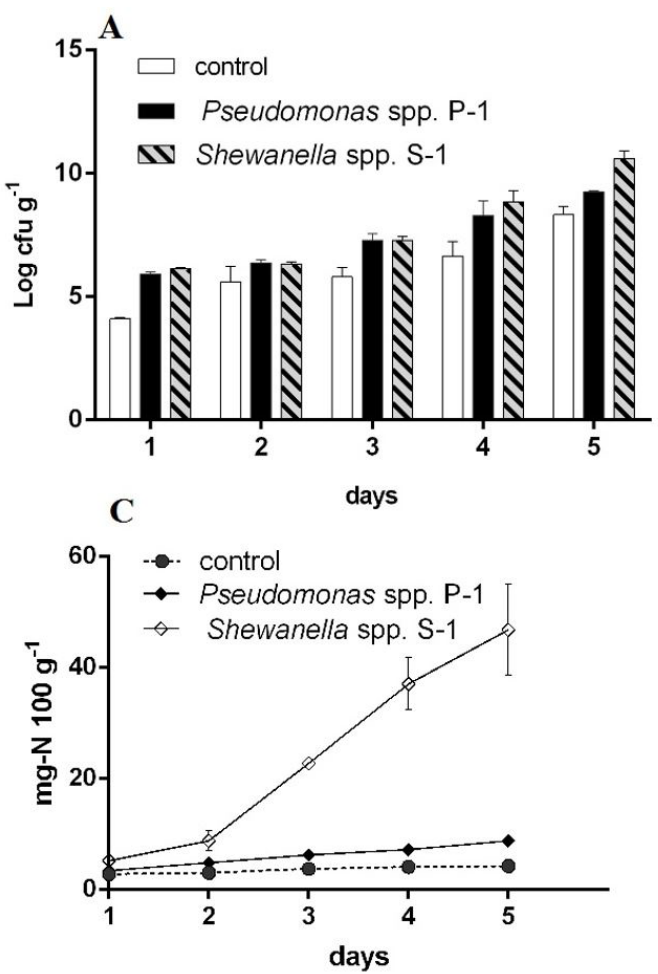

The TMA values of samples inoculated with Shewanella spp. reached $45 \mathrm{mg}-\mathrm{N} 100 \mathrm{~g} \mathrm{~g}^{-1}$ at the end of the storage period (Figure 1C). However, the TMA values of samples inoculated with Pseudomonas spp. were near $10 \mathrm{mg}-\mathrm{N} 100 \mathrm{~g}^{-1}$. Conversely, the values of the control samples were $4.24 \mathrm{mg}-\mathrm{N} 100 \mathrm{gg}^{-1}$, which was lower than the upper acceptable limit of $10 \mathrm{mg}-\mathrm{N}$ $100 \mathrm{~g}^{-1}$ (Teskeredzic \& Pfeifer, 1987). TMA is produced by the decomposition of TMAO due to bacterial spoilage and enzymatic activity. It has been reported that two Pseudomonas spp. strains isolated from large yellow croaker are unable to produce TMA. Additionally, the TVB-N value of S. baltica was significantly higher than that of Pseudomonas spp. in sterile fish juice, although its growth was slower than that of Pseudomonas spp. (Ge et al., 2017).

The $\mathrm{K}$ value, the ratio of ATP-related compounds, is widely utilized to assess the freshness of refrigerated fish. $\mathrm{K}$ values $<20 \%$ are very fresh, those of $20-60 \%$ are moderately fresh, and $>60 \%$ should be rejected (Ehira, 1976). As shown in Figure 1D, the initial $\mathrm{K}$ values were near $20 \%$. The $\mathrm{K}$ values of fillets inoculated with Shewanella spp. exceeded the recommended limit value (60\%) after four days. However, the K values of fillets inoculated with Pseudomonas spp. were still acceptable on day 4.

\subsection{In vitro adhesion of spoilage bacteria and inhibition by Bacillus subtilis}

As shown in Figure 2A, adhesion of Shewanella spp. S-1 to the intestinal mucus of large yellow croaker was significantly higher than Pseudomonas spp. P-1. However, adhesion of spoilage bacteria was inhibited by Bacillus subtilis BS08 (Figure 2B).

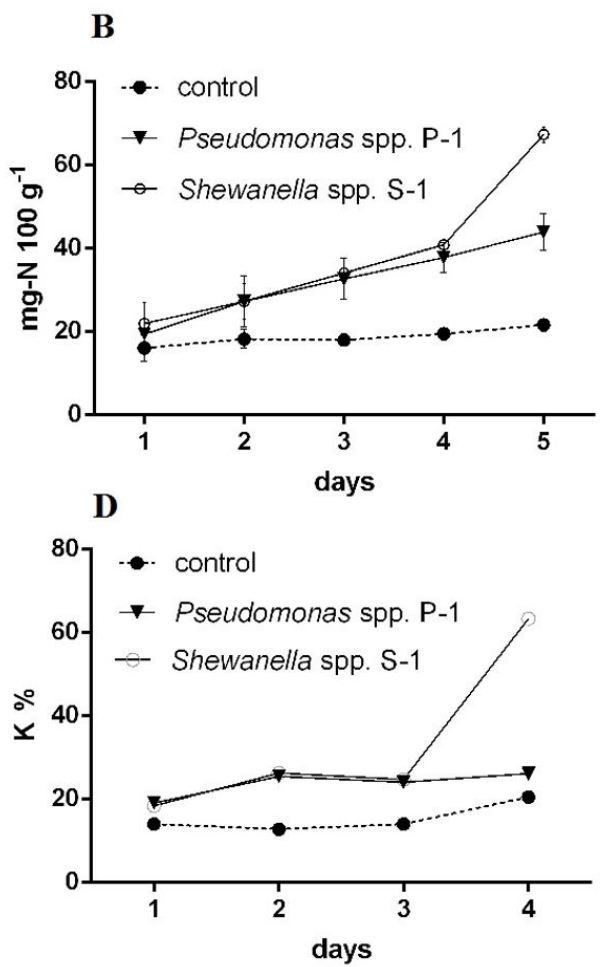

Figure 1. In vitro evaluation of spoilage potential of Shewanella spp. S-1 and Pseudomonas spp. P-1 by inoculating cultures on Large yellow croaker fillets at $4{ }^{\circ} \mathrm{C}$ storage. (A) Total viable counts; (B) TVB-N value; (C) TMA value; (D) K values. 

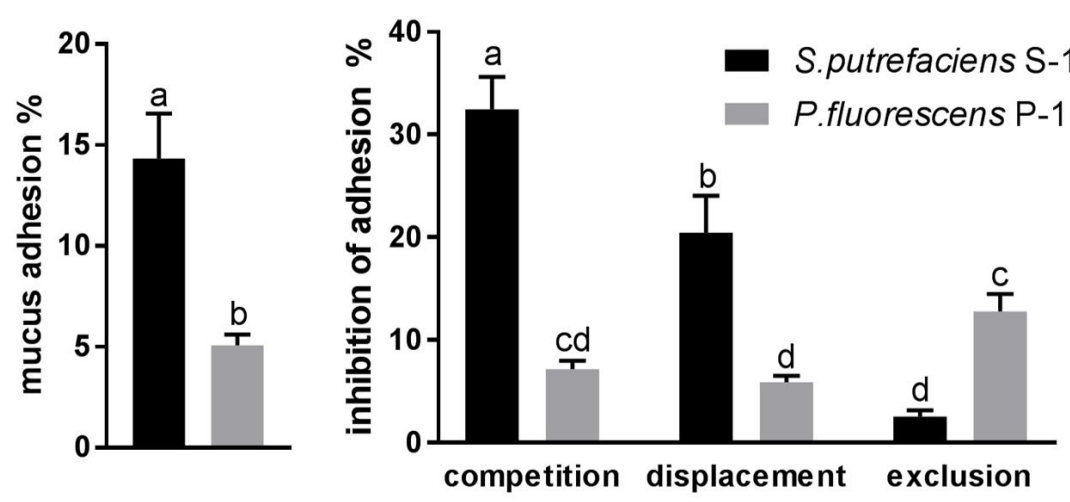

Figure 2. Adhesion of Shewanella spp. S-1 and Pseudomonas spp. P-1 to intestinal mucus of large yellow croaker and inhibition by Bacillus Subtilis (BS08) in vitro.

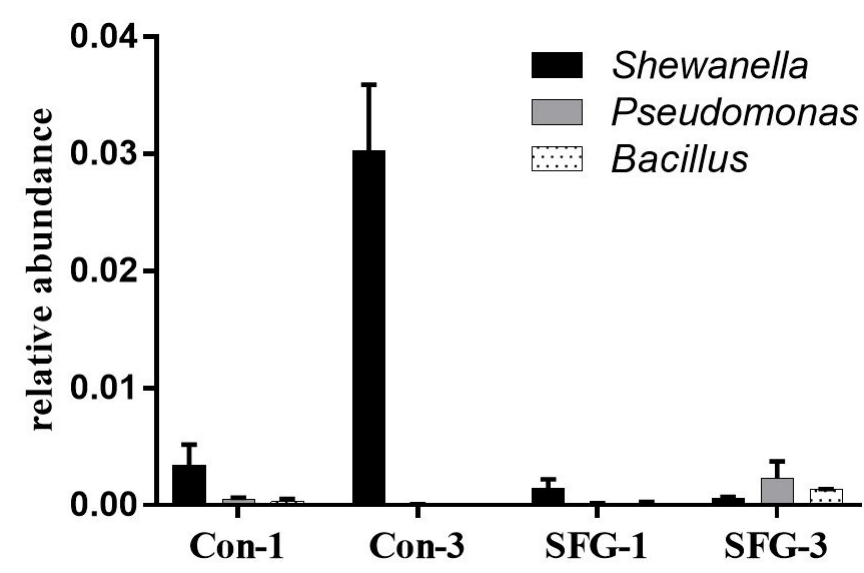

Figure 3. Relative abundance of Shewanella, Pseudomonas, and Bacillus analyzed by high-throughput sequencing analysis.

The adhesion of Shewanella spp. to intestinal mucus was significantly inhibited by competition and displacement of Bacillus subtilis, while adhesion of Pseudomonas spp. was significantly inhibited by exclusion.

\subsection{In vivo inhibition of adhesion by Bacillus subtilis}

In vivo experiments were carried out to evaluate the inhibitory effects of Bacillus subtilis BS08 against Shewanella and Pseudomonas in the intestines of large yellow croaker.

As shown in Figure 3, high-throughput sequencing of intestinal flora of large yellow croaker revealed that the relative abundance of Shewanella were higher than Pseudomonas in the control group on day 1 and increased sharply 3 days later (Con_3). Conversely, the relative abundance of Shewanella decreased in the supplement feed group (SFG). The results indicate Shewanella could adhere and grow better than Pseudomona in the intestines of large yellow croaker under natural water condition, but Shewanella were significantly inhibited by Bacillus subtilis.

The qPCR results in Figure 4 show that adhesion and colonization of Shewanella and Pseudomonas in the intestine of large yellow croaker were better than Bacillus subtilis. However, the growth of Shewanella in large yellow croaker intestinal tract and proliferation to the flesh were significantly inhibited by Bacillus subtilis. The inhibition of Pseudomonas was slightly weaker than that of Shewanella, which was consistent with the inhibition of adhesion in vitro.

As shown in Figure 5A, TVB-N values in the control and supplement feed groups were near $20 \mathrm{mg}-\mathrm{N} 100 \mathrm{~g}^{-1}$ at the initial stage of storage. The values in the control group were higher (27.87 mg-N $100 \mathrm{~g} \mathrm{~g}^{-1}$, near the upper acceptable limit $30 \mathrm{mg} / 100 \mathrm{~g}$ ) than those in the supplement feed group (SFG_3) on day 3. K values are shown in Figure 5B. The freshness of large yellow croaker was significantly different after three days of storage. The results show that treatment with Bacillus subtilis could significantly delay the spoilage of large yellow croaker.

\section{Discussion}

Shewanella and Pseudomonas are widely known to be responsible for the spoilage of fish. In this study, the TVC, TVB-N, TMA, and K values of Shewanella spp. were higher than those of Pseudomonas spp.. Shewanella is considered a spoilage bacterium due to its ability to induce TMAO reduction to trimethylamine (TMA), which is associated with the typical strong fishy, urine, and ammonia-like off-odors (Gram \& Huss, 1996; López-Caballero et al., 2001). The TVB-N value of Shewanella spp. inoculated in sterile fish juice of large yellow croaker was previously found to be significantly higher than that of Pseudomonas (Ge et al., 2017), which was consistent with our research.

As exogenous microorganisms of large yellow croaker, the adhesion of Shewanella and Pseudomonas is important for colonization. In this study, the adhesion ability of Shewanella spp. S-1 and Pseudomonas spp. P-1 were determined in vitro. The results show that the adhesion of Shewanella spp. to intestinal mucus was higher than that of Pseudomonas spp.. Furthermore, in vivo tests showed that Shewanella had better adhesion than Pseudomonas. Shewanella then spread and proliferated to the flesh, and this result was in accordance with adhesion in vitro. Although there are few adhesion studies regarding mucus adhesion of spoilage bacteria, pathogenesis studies indicate that the adherence and invasive capacities of bacteria are important in early pathogenesis. It has been suggested that pathogenic bacteria in the gill adhere to the gill mucus and thereafter invade 

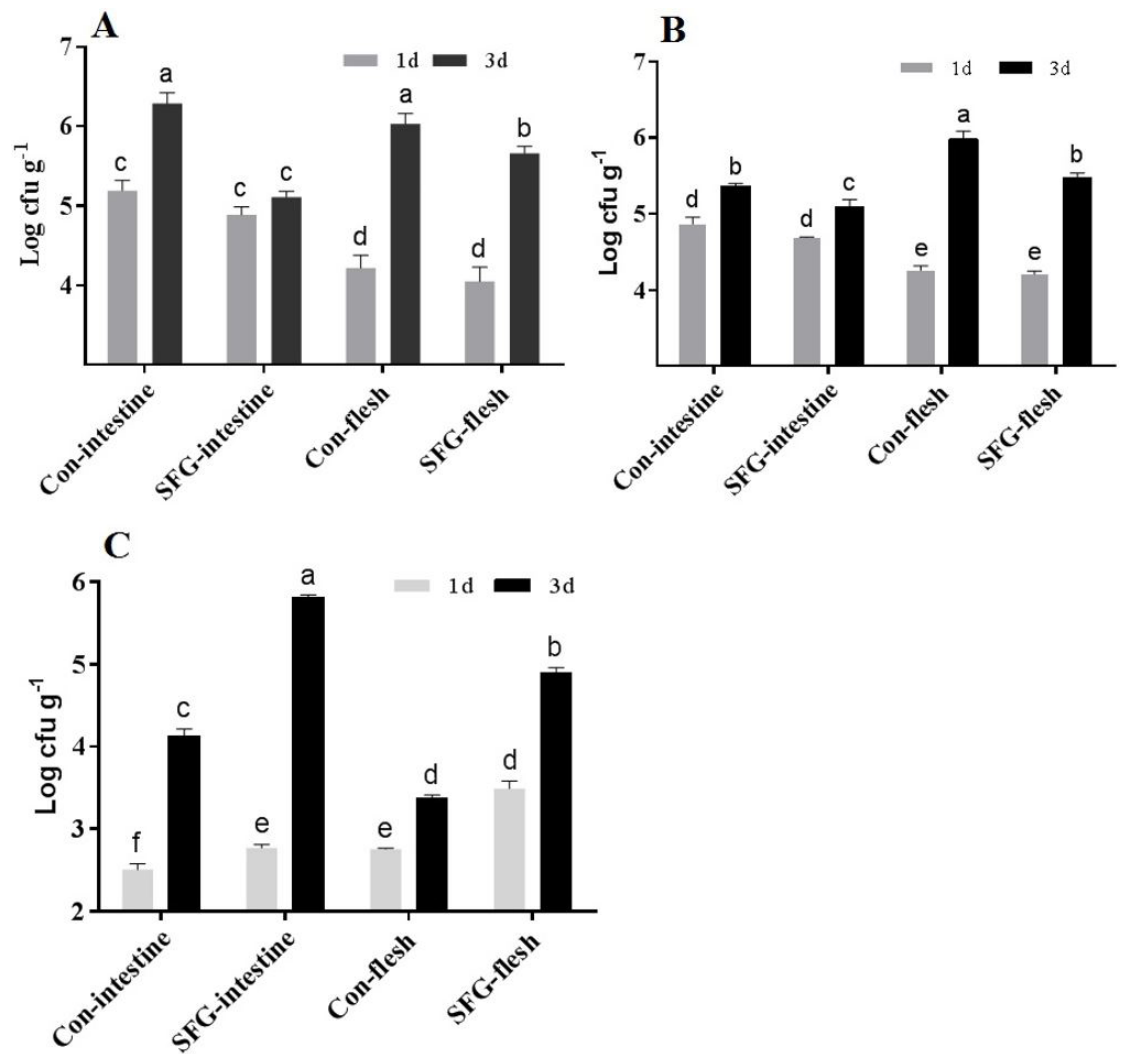

Figure 4. qPCR analysis of bacterial growth in intestine and flesh of large yellow croaker during storage at $4{ }^{\circ} \mathrm{C}$. (A) Shewanella; (B) Pseudomonas; (C) Bacillus.
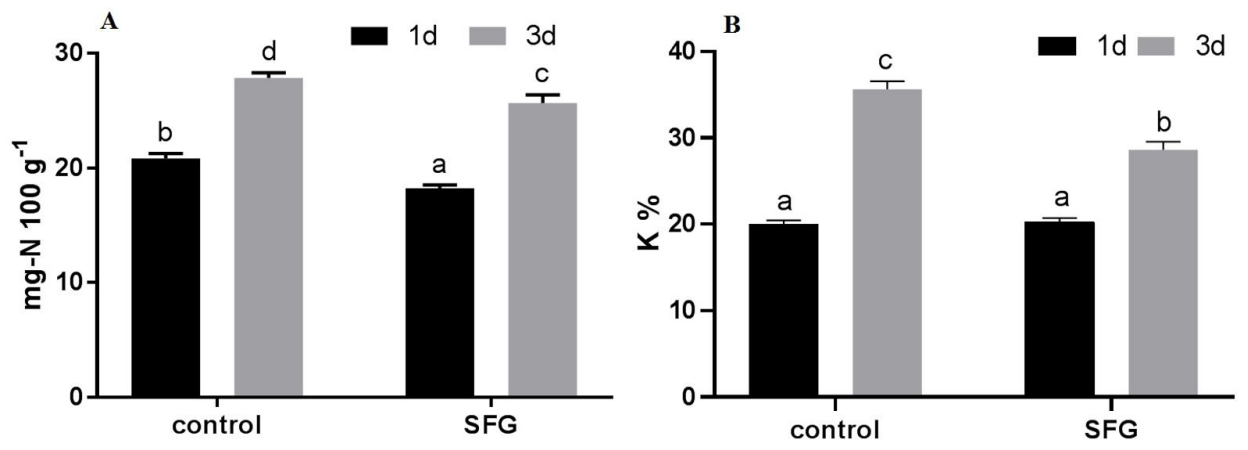

Figure 5. Effect of Bacillus subtilis (BS08) on freshness of large yellow croaker stored at $4{ }^{\circ} \mathrm{C}$. (A) TVB-N value of large yellow croaker; (B) K value of large yellow croaker.

the branchial vasculature, leading to septicemia and colonization of the internal organs (Tobback et al., 2009).

The results in vitro show that Bacillus subtilis inhibited the adhesion of Shewanella spp. and Pseudomonas spp. to intestinal mucus of large yellow croaker through competition, displacement, and exclusion. The adhesion of Shewanella spp. to intestinal mucus was significantly inhibited by competition and replacement inhibition of B. subtilis, while Pseudomonas spp. was significantly inhibited by exclusion. The results of in vivo experiments showed that B. subtilis could effectively inhibit the growth of Shewanella in the intestinal tract and the proliferation to the flesh of large yellow croaker during storage, but B. subtilis had no significant effect on Pseudomonas. Our findings indicated that competitive inhibition and displacement inhibition of B. subtilis might play important roles in the intestinal tract. The TVB-N and $\mathrm{K}$ values of samples mediated with Bacillus subtilis changed slowly during storage. Thus, we concluded that Bacillus subtilis delayed spoilage of fish through adhesion inhibition. Since the infections of spoilage bacteria usually originate in former colonization, decolonization should be a possible means of preventing the infection of spoilage bacteria. Inhibitory and adhesive abilities are regarded as indictors for the screening of potential probiotic, such as lactic acid bacteria and Bacillus species (Etyemez \& Balcazar, 2016), against pathogenic bacteria. This study showed B. subtilis could be used as a probiotic in aquaculture against spoilage bacteria. Studies have found a widespread mechanism exerted by Bacillus subtilis species that inhibits adhesion, colonization, and growth of spoilage bacteria. For example, Bacillus inhibited S. aureus intestinal colonization through an Agr quorum sensing regulatory system (Piewngam et al., 2018). Our findings suggest 
a probiotic-based method for spoilage bacteria decolonization and new ways to fight spoilage in aquatic foods.

In conclusion, the spoilage ability of Shewanella spp. in the flesh of large yellow croaker was higher than that of Pseudomonas spp.. Shewanella spp. adhesion to fish intestinal mucus was significantly greater than that of Pseudomonas spp. in vitro. Further fish feeding experiments showed that Shewanella more easily adhered to fish intestines than Pseudomonas and formed specific spoilage bacteria without the interference of exogenous microorganisms. Subsequently, Shewanella proliferated to the flesh and produced a strong spoilage effect. Bacillus subtilis strain BS08 inhibited the adhesion of Shewanella to fish intestinal mucus in vitro and inhibited the adhesion and growth of Shewanella in the intestines of large yellow croaker, delaying spoilage. The results of this study suggest that the usage of Bacillus subtilis in fish might become a new way of preservation.

\section{Acknowledgements}

This work was financially supported by National Natural Science Foundation of China (No. 31601532), the Science Foundation of the Fujian Province, China (No. 2020J01487) and the Science and technology project of Fuzhou (No. 2020-GX-13).

\section{References}

Arellano-Ayala, K., Ascencio-Valle, F. J., Gutiérrez-González, P., EstradaGirón, Y., Torres-Vitela, M. R., \& Macías-Rodríguez, M. E. (2020). Hydrophobic and adhesive patterns of lactic acid bacteria and their antagonism against foodborne pathogens on tomato surface (Solanum lycopersicum L.). Journal of Applied Microbiology, 129(4), 876-891. http://dx.doi.org/10.1111/jam.14672. PMid:32320113.

Association of Official Analytical Chemists - AOAC. (1990). Official methods of analysis (15th ed.). Arlington: AOAC.

Chen, Q., Yan, Q. P., Wang, K. J., Zhuang, Z. X., \& Wang, X. R. (2008). Portal of entry for pathogenic Vibrio alginolyticus into large yellow croaker Pseudosciaena crocea, and characteristics of bacterial adhesion to mucus. Diseases of Aquatic Organisms, 80(3), 181-188. http://dx.doi.org/10.3354/dao01933. PMid:18814543.

Chytiri, S., Chouliara, I., Savvaidis, I. N., \& Kontominas, M. G. (2004). Microbiological, chemical and sensory assessment of iced whole and filleted aquacultured rainbow trout. Food Microbiology, 21(2), 157-165. http://dx.doi.org/10.1016/S0740-0020(03)00059-5.

Ehira, S. (1976). A biochemical study on the freshness of fish. Bulletin of Tohoku Regional Fisheries Research Laboratory, 88, 1-132.

Etyemez, M., \& Balcazar, J. L. (2016). Isolation and characterization of bacteria with antibacterial properties from Nile tilapia (Oreochromis niloticus). Research in Veterinary Science, 105, 62-64. http://dx.doi. org/10.1016/j.rvsc.2016.01.019. PMid:27033910.

Fu, L. L., Wang, C., Liu, N. N., Ma, A. J., \& Wang, Y. B. (2018a). Quorum sensing system-regulated genes affect the spoilage potential of Shewanella baltica. Food Research International, 107, 1-9. http:// dx.doi.org/10.1016/j.foodres.2018.01.067. PMid:29580465.

Fu, L. L., Wang, C., Ruan, X. M., Li, G., Zhao, Y., \& Wang, Y. B. (2018b). Preservation of large yellow croaker (Pseudosciaena crocea) by Coagulin L1208, a novel bacteriocin produced by Bacillus coagulans L1208. International Journal of Food Microbiology, 266, 60-68. http:// dx.doi.org/10.1016/j.ijfoodmicro.2017.11.012. PMid:29179097.
Ge, Y., Zhu, J., Ye, X., \& Yang, Y. (2017). Spoilage potential characterization of Shewanella and Pseudomonas isolated from spoiled large yellow croaker (Pseudosciaena crocea). Letters in Applied Microbiology, 64(1), 86-93. http://dx.doi.org/10.1111/lam.12687. PMid:27747903.

Gimenez, B., Roncales, P., \& Beltran, J. A. (2002). Modified atmosphere packaging of filleted rainbow trout. Journal of the Science of Food and Agriculture, 82(10), 1154-1159. http://dx.doi.org/10.1002/jsfa.1136.

Gram, L., \& Dalgaard, P. (2002). Fish spoilage bacteria: problems and solutions. Current Opinion in Biotechnology, 13(3), 262-266. http:// dx.doi.org/10.1016/S0958-1669(02)00309-9. PMid:12180103.

Gram, L., \& Huss, H. H. (1996). Microbiological spoilage of fish and fish products. International Journal of Food Microbiology, 33(1), 121-137. http://dx.doi.org/10.1016/0168-1605(96)01134-8. PMid:8913813.

Hartree, E. F. (1972). Determination of protein: a modification of the lowry method that gives a linear photometric response. Analytical Biochemistry, 48(2), 422-427. http://dx.doi.org/10.1016/00032697(72)90094-2. PMid:4115981.

He, M., Guo, Q. Y., Song, W., Li, B. G., \& Zhang, G. W. (2017). Inhibitory effects of chitosan combined with nisin on Shewanella spp. isolated from Pseudosciaena crocea. Food Control, 79, 349-355. http://dx.doi. org/10.1016/j.foodcont.2017.04.012.

Kavitha, M., Raja, M., \& Perumal, P. (2018). Evaluation of probiotic potential of Bacillus spp. isolated from the digestive tract of freshwater fish Labeo calbasu (Hamilton, 1822). Aquaculture Reports, 11, 59-69. http://dx.doi.org/10.1016/j.aqrep.2018.07.001.

Kos, B., Suskovic, J., Vukovic, S., Simpraga, M., Frece, J., \& Matosic, S. (2003). Adhesion and aggregation ability of probiotic strain Lactobacillus acidophilus M92. Journal of Applied Microbiology, 94(6), 981-987. http://dx.doi.org/10.1046/j.1365-2672.2003.01915.x. PMid:12752805.

Liu, M., \& Mitcheson, Y. S. (2008). Profile of a fishery collapse: why mariculture failed to save the large yellow croaker. Fish and Fisheries, 9(3), 219-242. http://dx.doi.org/10.1111/j.1467-2979.2008.00278.x.

López-Caballero, M. E., Sanchez-Fernandez, J. A., \& Moral, A. (2001). Growth and metabolic activity of Shewanella putrefaciens maintained under different $\mathrm{CO}_{2}$ and $\mathrm{O}_{2}$ concentrations. International Journal of Food Microbiology, 64(3), 277-287. http://dx.doi.org/10.1016/ S0168-1605(00)00473-6. PMid:11294349.

Malle, P., \& Poumeyrol, M. (1989). A new chemical criterion for the quality-control of fish - trimethylamine total volatile basic nitrogen. Journal of Food Protection, 52(6), 419-423. http://dx.doi. org/10.4315/0362-028X-52.6.419. PMid:31003301.

Nwanna, L. C., Ajani, E. K., \& Bamidele, S. F. (2014). Use of lactic acid bacteria from Nile tilapia Oreochromis niloticus as probiotics for sustainable production and improvement in fish welfare. Israeli Journal of Aquaculture - Bamidgeh, 66, 1-12.

Ojagh, S. M., Rezaei, M., Razavi, S. H., \& Hosseini, S. M. H. (2010). Effect of chitosan coatings enriched with cinnamon oil on the quality of refrigerated rainbow trout. Food Chemistry, 120(1), 193-198. http://dx.doi.org/10.1016/j.foodchem.2009.10.006.

Piewngam, P., Zheng, Y., Nguyen, T. H., Dickey, S. W., Joo, H. S., Villaruz, A. E., Glose, K. A., Fisher, E. L., Hunt, R. L., Li, B., Chiou, J., Pharkjaksu, S., Khongthong, S., Cheung, G. Y. C., Kiratisin, P., \& Otto, M. (2018). Pathogen elimination by probiotic Bacillus via signalling interference. Nature, 562(7728), 532-537. http://dx.doi. org/10.1038/s41586-018-0616-y. PMid:30305736.

Quanyou, G., Yanqi, Z., Lumin, W., Baoguo, L., \& Chaojun, J. (2018). Shelf life prediction and bacterial flora for the fresh and lightly salted Pseudosciaena crocea stored at different temperatures. Emirates Journal 
of Food and Agriculture, 30(1), 39-48. http://dx.doi.org/10.9755/ ejfa.2018.v30.i1.1583.

Reid, G., Howard, J., \& Gan, B. S. (2001). Can bacterial interference prevent infection? Trends in Microbiology, 9(9), 424-428. http:// dx.doi.org/10.1016/S0966-842X(01)02132-1. PMid:11553454.

Teskeredzic, Z., \& Pfeifer, K. (1987). Determining the degree of freshness of rainbow-trout (Salmo-Gairdneri) cultured in brackish water. Journal of Food Science, 52(4), 1101-1102. http://dx.doi. org/10.1111/j.1365-2621.1987.tb14286.x.

Tobback, E., Decostere, A., Hermans, K., Ryckaert, J., Duchateau, L., Haesebrouck, F., \& Chiers, K. (2009). Route of entry and tissue distribution of Yersinia ruckeri in experimentally infected rainbow trout Oncorhynchus mykiss. Diseases of Aquatic Organisms, 84(3), 219-228. http://dx.doi.org/10.3354/dao02057. PMid:19565699.

Vendrell, D., Balcazar, J. L., Calvo, A. C., de Blas, I., Ruiz-Zarzuela, I., Girones, O., \& Muzquiz, J. L. (2009). Quantitative analysis of bacterial adhesion to fish tissue. Colloids and Surfaces. B, Biointerfaces, 71(2), 331-333. http://dx.doi.org/10.1016/j.colsurfb.2009.03.003. PMid:19349152.

Vinderola, C. G., Medici, M., \& Perdigon, G. (2004). Relationship between interaction sites in the gut, hydrophobicity, mucosal immunomodulating capacities and cell wall protein profiles in indigenous and exogenous bacteria. Journal of Applied Microbiology, 96(2), 230-243. http://dx.doi.org/10.1046/j.1365-2672.2004.02158.x. PMid:14723684.

Yu, D. W., Regenstein, J. M., Zang, J. H., Jiang, Q. X., Xia, W. S., \& Xu, Y. S. (2018). Inhibition of microbial spoilage of grass carp
(Ctenopharyngodon idellus) fillets with a chitosan-based coating during refrigerated storage. International Journal of Food Microbiology, 285, 61-68. http://dx.doi.org/10.1016/j.ijfoodmicro.2018.07.010. PMid:30031352.

Zhang, W., Bian, D., Shen, Y. Q., Wang, W. S., Liu, Z. B., \& Ni, L. (2017). Identification and characterization of antibacterial metabolites and optimization of cultural conditions for Bacillus subtilis. Journal of Chinese Institute of Food Science and Technology, 12, 105-115. http:// dx.doi.org/10.16429/j.1009-7848.2017.12.014.

Zhang, W., Bian, D., Ruan, C. X., Shi, X. Z., \& Ni, L. (2019a). Adhesive properties and biofilm characteristics of Pseudosciaena crocea spoilage bacteria. Shipin Kexue, 40(14), 84-90. http://dx.doi.org/10.7506/ spkx1002-6630-20180730-369.

Zhang, W., Bian, D., Wang, F. T., Zhang, C., \& Ni, L. (2019b). The ability of spoilage and adhesion of spoilage bacteria isolated from large yellow croaker (Pseudosciaena crocea). Journal of Chinese Institute of Food Science and Technology, 19(1), 117-124. http://dx.doi.org/ 10.16429/j.1009-7848.2017.12.014.

Zhu, J. L., Huang, X. Z., Zhang, F., Feng, L. F., \& Li, J. R. (2015). Inhibition of quorum sensing, biofilm, and spoilage potential in Shewanella baltica by green tea polyphenols. Journal of Microbiology, 53(12), 829836. http://dx.doi.org/10.1007/s12275-015-5123-3. PMid:26626353.

Zhu, J. L., Zhao, A. F., Feng, L. F., \& Gao, H. C. (2016). Quorum sensing signals affect spoilage of refrigerated large yellow croaker (Pseudosciaena crocea) by Shewanella baltica. International Journal of Food Microbiology, 217, 146-155. http://dx.doi.org/10.1016/j. ijfoodmicro.2015.10.020. PMid:26519730. 